\title{
Criteria for planning sustainable tourism development zones in coastal regions: case study of Croatia
}

\author{
N. Ivandić \& N. Telišman-Košuta \\ Institute for Tourism, Croatia
}

\begin{abstract}
Spatial planning of tourism zones outside settlements is of crucial importance to tourism development in Croatia as the characteristics of tourism zones significantly impact on the competitiveness of tourism products being created there. The issue is of particular significance for tourism development of Croatia's highly pressured protected coastal area. Despite the country's long established tradition of spatial and tourism planning a critical, multidisciplinary and integrated planning of tourism zones is still largely missing. This paper proposes a system of interrelated ecological, social and economic criteria for evaluating and planning of tourism zones in Croatia. The system is envisioned as a tool contributing to spatial planning of sustainable tourism development.

Keywords: tourism development, coastal regions, spatial planning, tourism planning, tourism zones, sustainability.
\end{abstract}

\section{Introduction}

It is an obvious fact that tourism is highly dependent on quality preserved natural and socio-cultural environments of destinations being, at the same time, an agent of their dramatic change and even degradation. It is becoming an obvious fact that public interest precedes other interest and that, encompassing environmental, social and economic aspects, sustainability is the imperative development concept of the $21^{\text {st }}$ century [1]. This is the framework within which spatial planning of tourism activity is becoming a central and critical issue to ensuring sustainable tourism development.

Although both spatial and tourism development planning have been long established practices in Croatia, a critical, multidisciplinary and integrated 
approach to spatial planning of tourism is still largely missing. More specifically, existing practice and regulation is proving inefficient in ensuring the planning of sustainable tourism zones outside settlements this being an especially critical issue for the country's highly pressured coastal regions and islands. This paper describes a proposed system of interrelated criteria for the evaluation of ecological, social and economic sustainability of potential tourism development zones. Each of these three components is further broken down into indicator sets allowing for a comprehensive, multifaceted and objective assessment of tourism zones. As such, the system could prove a valuable tool for spatial and tourism planners at local and regional levels in producing sustainable spatial and tourism development plans.

\section{Key market trends shaping the tourism industry}

The tourism industry has been experiencing dramatic change within the last two decades brought on by profound shifts within social, economic and technological environments in developed markets leading to their transition toward postmaterialistic experience economies. Altering of values from 'having' to 'doing and experiencing' has led to altering of consumer needs, expectations and behaviour. Thus, the 'new tourist' is an individual with a pronounced need for self-actualization, seeking experiences and activities which contribute to learning and personal growth, interested in authenticity and local identity of visited places, environmentally and increasingly socially responsible $[2,3]$.

Adapting to the 'new tourist' is altering the nature of the tourism business making it increasingly more complex. For one, there has been an intense tourism product diversification process under way geared to meeting the needs of an ever more segmented market [4]. Even the 'sun and beach' product, expected to continue dominating the tourism market [4], is being diversified with numerous 'beyond the beach' concepts. Master planning of tourism projects is also being taken to a new level. 'Next generation' accommodation facilities, whether hotels, camping complexes or mixed use resorts, are being programmed to deliver innovation and experiences through 'sense of place', atmosphere, themes and design [5]. Finally, a whole new relationship between tourism and the environment is evolving. Once considered the 'devourer of landscape' [6], the tourism industry is becoming increasingly environmentally sensitive with 'green' practices slowly but surely entering the mainstream [7].

\section{Tourism in Croatia}

Croatia is part of the Mediterranean tourism sub-region, this being the world's leading receptive tourism destination characterized today by a mature 'sun and sea' product, intense intra-regional competition and being, at the same time, challenged with steadily decreasing market share [8]. Similar to most of its regional competitors, Croatia's tourism industry, accounting directly for $8.3 \%$ and indirectly for $14.7 \%$ of the country's GDP [9], is also oriented towards the 
'sun and sea' product and, thus, heavily dependent on the country's coastal natural resources.

The Adriatic coast and islands are, in fact, Croatia's single most important tourism attraction. Most of the country's tourism accommodation capacity, amounting to $84 \%$ of total beds, is located in the seven coastal counties [10]. Vast majority, or $96 \%$, of total tourism overnights are also realized in this narrow coastal stretch [10]. The dependence on the 'sun and sea' product results in pronounced seasonality with $84 \%$ of overnights being registered from June to September and $61 \%$ in July and August [10]. Additionally, the coastline is dotted with approximately 240.000 housing units not used for permanent residence [11]. This creates peaks of tremendous pressure on the coastal resource base, followed by prolonged periods of suboptimal use.

Although 'sun and sea' will undoubtedly continue being one of Croatia's most important tourism products, reducing seasonality and spatial concentration while, at the same time, ensuring further growth of tourism activity is imperative. In this sense, accessing new market segments and subsequent product diversification supported by investment in, for example, new and innovative recreation, amusement, health, nautical and business facilities, changing the structure of accommodation capacity in favour of higher quality hotels and tourism resorts or the creation of additional protected nature areas, are all parts of a new re-invented destination which need to be supported by sustainable tourism master and spatial planning.

\section{The process and issues of spatial planning for tourism in Croatia}

Croatia draws upon a long established tradition of compulsory spatial planning organized, under the Physical Planning and Building Act, as a hierarchical system encompassing state, regional (county), municipal and sub-municipal levels each in charge of producing interdependent strategic and operational physical planning documents [12].

In accordance with the Physical Planning and Building Act, spatial planning governing tourism development in Croatia's prime and highly pressured protected coastal area, spanning all the islands, as well as the mainland area 1000 meters inland and 300 meters into the sea from the coastal line, is at the strategic level the domain of County Spatial Plans [12]. From tourism development perspective, particularly significant is the planning of so called tourism zones outside settlements as their characteristics significantly bear on the quality and ultimately on the competitive capability of tourism products being created there. The law stipulates tourism zones outside settlements can cover up to 15 hectares with a maximum density of 120 beds per hectare, differentiating five zone types, namely: hotel zones (marked as T1), tourism settlement zones (T2), campsite zones (T3), nautical tourism ports and golf course zones [12].

Most tourism zones are located within the protected coastal area. Currently, there are 564 tourism zones outside settlements within the protected coastal area included in County Spatial Plans of Croatia's seven coastal counties. Among 
them, 245 are on the islands. Almost three-quarters (72\%) of the tourism zones remain, however, wholly or mostly undeveloped with the situation showing little change over the past ten years [13-19]. Apart from the obvious questions as to the sustainability and even the desirability of such a large number of tourism zones, particularly on the islands, and taking into account the prolonged unfavourable investment climate in Croatia, the causes of the inability to materialize more, essentially needed, tourism development projects within the zones may, to a large extent, lie in the process of tourism zone planning.

Tourism zones are rarely planned conceptually on the basis of a coordinated effort between tourism and spatial planners or between counties. More often they are the result of a mechanical taking over of sites from previous physical plans and of uniform tourism development programs which do not sufficiently take into account the uniqueness of destinations, their possible brands and distinctive local features [20]. There is also a lack of clear and precise criteria for the evaluation and selection of tourism zones.

\section{Proposed system for evaluating and planning tourism zones in coastal regions of Croatia}

Being a part of spatial and tourism development planning processes, ecological, social and economic criteria for the evaluation and planning of tourism zones outside settlements are envisioned as a pyramid shaped system illustrated in Figure 1.

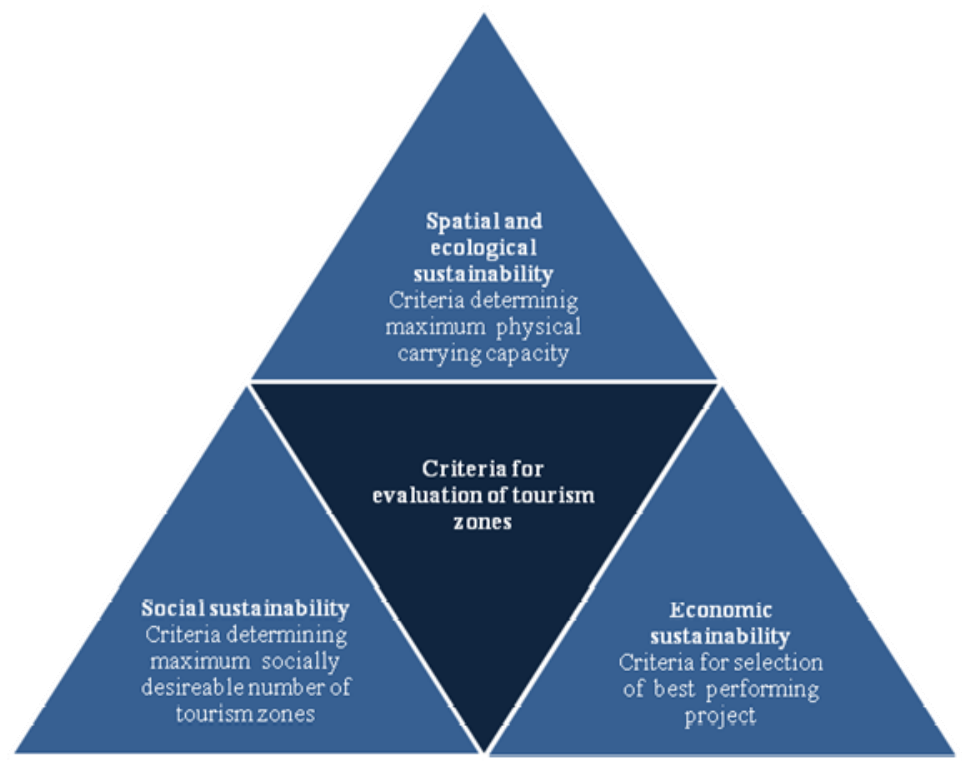

Figure 1: $\quad$ System of criteria for evaluation of tourism zones. 
Starting with the criteria of spatial and ecological sustainability to determine the maximum number of tourism zones outside settlements physically and ecologically suitable, the system presupposes further screening of tourism zones based on the criteria of social and economic sustainability. Each of these three system components is broken down into indicator sets illustrated in Figure 2 and explained in the remainder of this section.

Strategic tourism destination development framework

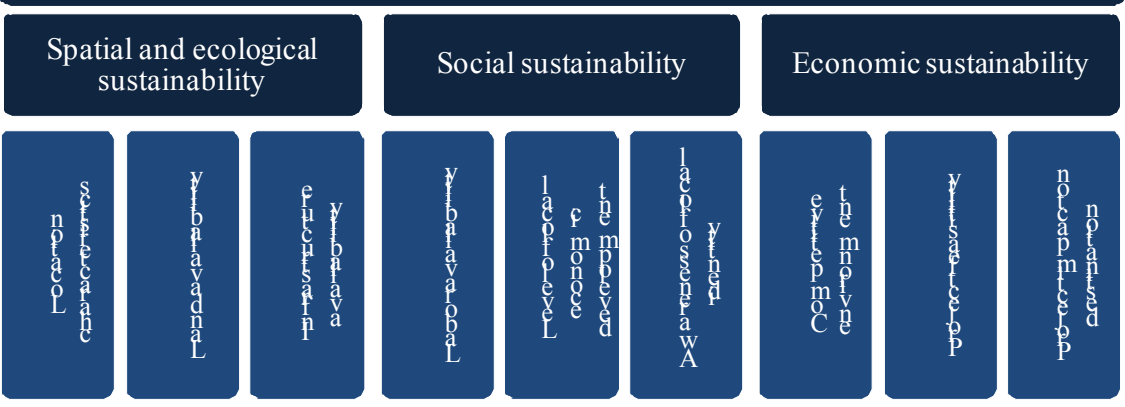

Figure 2: $\quad$ Hierarchy of criteria for evaluation of tourism zones.

\subsection{Spatial and ecological sustainability criteria}

Criteria of spatial and ecological sustainability evaluate possible tourism zones in terms of their physical features and impacts of tourism development within zones on the destination environment. The criteria are the basis for determining the total number of possible tourism zones outside settlements within the protected coastal area and also for determining each zone's maximum capacity.

\subsubsection{Location characteristics}

Location characteristics are assessed in relation to the quality of natural features of the zone itself and the quality of its surroundings. The criteria are relative as the desirable features and the importance of each criterion can vary depending on tourism products being considered in the tourism zone. Included are:

- Climate quality: assessment of climate (main desirable features are moderation, stability, pleasure, wind protection or mild winds);

- Sea quality: assessment of sea purity (main desirable features are high level of cleanliness, high transparency, without sources of cold currents);

- Air quality: assessment of air quality (main desirable features are air cleanliness below legally limited values);

- Orientation: assessment of quality of orientation (preferred are west or south-west orientation for maximum sun exposure and natural light);

- Beach quality: assessment of beach quality (main desirable features of manmade and natural beaches include accessibility, size, cover, access to the sea, natural shade); 
- Terrain quality: assessment of terrain (desirable features are slight elevation for better viewpoints, landscape diversity, namely bays, valleys, wooded areas, spatial harmony and attractiveness);

- Sensitivity of natural and anthropogenic environment in the area: assessment of sensitivity of the natural and anthropogenic resources in relation to increased tourism generated usage (desirable feature is capacity of the zone being lower than the carrying capacity of the resources);

- Attractiveness of natural and anthropogenic resources in the area: assessment of attractiveness of the natural and anthropogenic resources in the area in terms of tourism usage (desirable features include high attractiveness of resources, proximity to zone);

- Existence of conflicting activities in the area: ascertaining the presence of activities in their nature conflicting with tourism and assessment of level of conflict (desirable features include absence of industrial polluting factories, landfills or isolation and limited visibility of such facilities);

- Attractiveness of views from the zone: assessment of attractiveness of the view in terms of tourism usage (desirable features include beautiful and scenic views of the natural and anthropogenic surroundings);

- Harmony of the zone and the surrounding areas: assessment of the visual harmony of the zone and the surrounding areas in terms of tourism usage (desirable features include the blending of the zone and its surroundings in a visually harmonious manner).

\subsubsection{Land availability}

Land availability is assessed in relation to total usable surface area of the zone and its possible physical capacity. Land requirement is relative and may vary depending on several factors. Namely, those zones located in closer proximity to existing destinations and having, thus, the possibility to rely on services provided within destinations can be smaller as opposed to further away zones which should be larger. The sensitivity of natural and anthropogenic resources in the surrounding areas can also influence the dimensions of the zone. Finally spatial requirements will depend upon the attributes of potential tourism products. Criteria include:

- Total usable surface area: evaluation of the total available surface area and, specifically evaluation of total construction space taking into account legal regulation stipulating a protected seaside belt 70 meters in width. Also assessment of extension or reduction possibilities (desirable features include availability of land for the realization of a competitive product, including accommodation and other necessary facilities);

- Existing facilities, size and relationship of different spatial entities within zone: evaluation of the existing non-tourism facilities and their usage. Further, assessment of construction areas as pertaining to level of building difficulty due to terrain characteristics, assessment of relationship between construction and non-construction areas, relationship between construction areas and beach size (desirable features include availability of land for the 
realization of a competitive product without content that is contrary to the basic functionality of the zone);

- Accommodation capacity: calculation of the maximum number of beds/rooms and guests given the physical characteristics of the zone and spatial planning regulation (desirable feature is that the maximum possible capacity is greater than that required for the feasibility of the project);

- Possibility of altering capacity: assessment of the possibility to increase the maximum number of beds/rooms if these are limited by factors such as the capacity of existing infrastructure, beach area or the topography of the terrain (desirable features include the possibility to compensate existing limitations through infrastructure and construction interventions).

\subsubsection{Infrastructure availability}

Infrastructure availability is assessed in relation to transport and utility infrastructure. Criteria include:

- Traffic accessibility of broader destination: evaluation of availability and quality of road, air and marine connections of broader destination in which the tourism zone is located (desirable features include a high level of accessibility);

- Traffic accessibility of tourism zone: assessment of the availability and quality of transport infrastructure to the zone, as well as the distance from the zone to the closest traffic connection (desirable features include a high level accessibility);

- Availability, capacity and quality of utility systems within the zone: availability and/or assessment of needs for construction of electricity, alternative energy, water supply, sewerage network, waste water treatment and solid waste management facilities (desirable features include the availability of utility systems within the zone);

- Distance to utility infrastructure to which the zone can be connected: estimation of the distance between the zone and utility infrastructure, which includes electricity, water and sewage networks, as well as wastewater treatment systems and solid waste management facilities (desirable features include the proximity of utility infrastructure to the zone);

- Capacity and quality of infrastructure systems to which the zone can be connected: assessment of the required and existing capacity of electricity, water and sewage networks, wastewater treatment systems and solid waste management facilities (desirable features include the existing capacity being sufficient to allow the connection of the zone).

\subsection{Social sustainability criteria}

Social sustainability criteria are aimed at determining the social carrying capacity or the ability of local communities to absorb new tourism projects in the tourism zones outside settlements within the protected coastal area. These criteria form the basis for determining the total desired number of tourism zones in the region or destination. 


\subsubsection{Labour availability}

Labour availability criteria assess local availability of qualified personnel, as well as the community's readiness and capability to absorb new labour from outside the local community. Included are:

- Availability of qualified local hospitality and tourism staff: number of local (within one hour by public transport radius from tourism zone) persons qualified for various hospitality and tourism jobs (e.g. cooks, waiters, chambermaids and reception staff, as well as support services such as maintenance, landscaping, etc.). Also availability of personnel for other types jobs in the tourism zone which, depending on the tourism product, may vary from medical staff to physical fitness trainers, etc. (desirable features include local availability of qualified staff capable of supporting product diversity within the zone);

- Availability of qualified local public sector personnel: assessment of the existing and required number of professional services personnel within the public sector (including urban planning, infrastructure, project management, tourism boards/destination management) qualified for managing tourism development, preparing and implementing projects in tourism zones (desirable features include sufficient availability of professional staff to perform all of the required tasks in accordance with the development dynamics of tourism zones);

- Capability of accepting seasonal hospitality and tourism staff: assessment of the need for seasonal labour and the availability of temporary accommodation for these seasonal workers (desirable features include readiness for seasonal labour and availability of accommodation for them);

- Capability and readiness of accepting full-time employees with permanent residence outside the local area: assessment of the need for recruitment of permanent employees from outside the local area, assessment of the local community's readiness to accept a larger number of 'foreign' employees and/or highly paid 'foreign' management staff, as well as assessment of housing availability (desirable features include openness of the local community towards permanent employment of 'foreign' workforce and availability of accommodation for them).

\subsubsection{Level of local economic development}

Local economic development criteria assess the strength of the local economy in supporting tourism development. Included criteria are:

- Availability of local products and services: assessment of the level at which the local economy participates in the tourism value chain of the destination and the tourism zones. While the criterion is not a prerequisite for planning of tourism zones, the participation of the local economy in tourism development is highly desirable. In this context, the availability of local food production, hospitality related equipment, catering, travel agency and other services need to be evaluated (desirable features include as highly developed a local tourism value chain as possible); 
- Local economic structure: evaluation of the potential threat that additional tourism zones pose to destinations in terms of the local economic structure being completely dependent on tourism (desirable features include achieving a balanced economic structure resulting from stakeholder consensus).

\subsubsection{Awareness of local identity}

Criteria assessing awareness of local identity evaluate the presence of traditional features in the destination's tourism offer. Included are:

- Awareness of spatial identity: assessment of the local community's awareness of specific spatial identity features, the need for their protection and even for barring tourism development in certain areas in order to maintain natural spatial characteristics;

- Awareness of cultural identity: assessment of the level to which local cultural heritage is or could be featured in projects in tourism zones. The criterion is not a prerequisite for planning of tourism zones, but may be an advantage (desirable features include high visibility of local cultural identity in tourism zones, particularly relevant here being building styles, building materials, horticulture).

\subsection{Economic sustainability criteria}

Economic sustainability criteria are designed to determine the market feasibility of projects planned within tourism zones, as well as their economic impact on the broader destination. These criteria form the basis for selecting the best tourism development zones, as well as for determining their minimum size and capacity.

\subsubsection{Competitive environment}

Understanding of the competitive environment includes analyses of relevant market trends and of competitor performance.

- Market trends: knowledge of long-term market trends is essential to understanding the competitive characteristics that need to be incorporated into the concepts underlying particular tourism zones. Specifically important is knowledge of how trends in the social environment, in technology and in environmental protection impact tourism (desirable features include stakeholders knowledgeable of relevant market trends and how these bear on development of competitive projects within tourism zones);

- Competitors: knowledge of products and services being offered by competitors is essential to determining the competitive positioning of particular tourism zones. Characteristics of the competitors' existing offer, new and planned projects should be analyzed in order to develop differentiated concepts (desirable features include stakeholder knowledge of competing offers and how these bear on development of projects within tourism zones). 


\subsubsection{Project feasibility}

Assessing the feasibility of projects planned within tourism zones involves tourism zone programming, investment estimation, financial and economic evaluations.

- Tourism zone programming: development of scenarios and selection of tourism product mix, facilities and capacity best suited to the tourism zone. The product mix must ensure operation during as long a period of the year as possible. The accommodation capacity within the zone is subject to physical and regulatory limitations (desirable features include tourism zone programming being carried out as a prerequisite of zone selection);

- Ownership of land, estimation of required investment and financing model: approximation of investment based on estimation of gross developed area of facilities and landscaped areas and average construction costs per square meter of comparable projects;

- Financial evaluation of the project: calculation of the project's free cash flow (the project is expected to generate a positive free cash flow during the entire operating period);

- Economic evaluation of the project: calculation of return of investment indicators, namely the internal rate of return (expected IRR is equal to or greater than the weighted average cost of capital for the project) and the net present value of the project (expected NPV is equal to or greater than value of investment at a discount rate equal to the weighted average cost of capital for the project).

\subsubsection{Project/tourism zone impact on destination}

Impacts of the project being developed within a particular tourism zone are assessed in terms of expected benefits and costs for the broader destination. Criteria involve:

- Destination image and recognisability: assessment of the influence project/tourism zone development can have on the image of the broader destination and the capability of contributing to or creating a positive destination image and increasing destination recognisability on the tourism market (preferred project/tourism zones are those with higher image impact potential);

- Visitor expenditure: assessment of expenditures in broader destination generated by guests staying in tourism zone (preferred project/tourism zones are those with higher per guest expenditure potential for broader destination);

- $\quad$ Cost of project preparation: estimation of project preparation costs for the municipality/town/county (preferred project/tourism zones are those with lower project preparation costs);

- Cost of destination development: estimation of costs of destination development, including improvements in infrastructure, traffic accessibility, urban features, beaches and horticulture, which are conditional to project/tourism zone development (preferred project/tourism zones are those with lower costs for destination development). 


\section{Conclusion}

The described system for evaluation of tourism zones based on an extensive set of interrelated environmental, social and economic criteria presents an attempt at a more critical and objective screening process of areas being planned as tourism development sites. It is intended as a tool for both spatial and tourism planners in producing sustainable spatial and tourism development plans. Inspired primarily by experiences and challenges of spatial planning and tourism development of Croatia's highly pressured protected coastal area, the system could be applicable in other parts as well.

The proposed system of criteria needs to be tested in practice. At this point in time providing a framework for discussion, the proposed criteria will surely need to be sharpened, adjusted and, most importantly, a weighting system reflecting the differing importance of the criteria themselves, but also in relation to characteristics of tourism zones and tourism products being considered should be developed. Institutionalizing a system of careful scrutiny of tourism zones is a step towards increasing the competitiveness of the tourism sector and a crucial issue for a tourism oriented economy such as Croatia's. It is also a step owed to the incredibly beautiful landscape Croatia has been endowed with.

\section{References}

[1] www.ec.europa.eu/europe2020

[2] Dwyer, L., (ed.). Megatrends Underpinning Tourism to 2020: Analysis of Key Drivers for Change, CRC for Sustainable Tourism: Gold Coast, Queensland, 2008.

[3] Nardin, S., Tourism of Tomorrow: Travel Trends and Forces of Change, European Tourism Research Institute: Ostersund, pp. 12-51, 2005.

[4] UNWTO, Tourism 2020 Vision: Global Forecasts and Profiles of Market Segments, UNWTO: Madrid, 2001.

[5] Hillier, I., Research Project and Benchmark of Tourism Resorts in the Mediterranean Region, VERUM and TEAM Tourism: Barcelona, 2010.

[6] Krippendorf, J., Putujuće čovječanstvo, Sveučilišna naklada Liber, Zavod za istraživanje turizma: Zagreb, pp. 75-76, 1986.

[7] Ball, M., Green Innovations in Tourism, Travel and Tourism Analyst, No 1, pp. 7-10, 2011.

[8] UNWTO Tourism Highlights, www.unwto.org

[9] Šutalo, I., Ivandić, N., Marušić, Z., Ukupan doprinos turizma gospodarstvu Hrvatske: Input-output model i satelitski račun turizma. Ekonomski pregled, 62(5-6), pp. 267-285, 2011.

[10] www.dzs.hr and www.iztzg.hr/hr/poslovna inteligencija/bist

[11] www.dzs.hr

[12] Physical Planning and Building Act. Official Gazette, 76/07, 2007.

[13] Changes and Additions of Istria County Spatial Plan. Istria County Official Gazette, 10/2008, pp. 535-550, 2008. 
[14] Correction of Adjustment of Primorsko-goranska County Spatial Plan, Primorsko-goranska County Official Gazette, 50/2006, pp. 4314-4318, 2006.

[15] Zavod za prostorno planiranje, razvoj i zaštitu okoliša Ličko-senjske županije, Changes and Addition of Lika-Senj County Spatial Plan, pp. 3841, 2007.

[16] Županijski zavod za prostorno planiranje Zadar, Adjustment of Zadar County Spatial Plan with Regulation on Protected Coastal Area, pp 1-12, 2004.

[17] Changes and Additions of Šibenik-Knin County Spatial Plan, Šibenik-Knin County Official Gazette, 3/2006, pp. 4-21, 2006.

[18] Adjustment of Split-Dalmatia County Spatial Plan with Regulation on Protected Coastal Area, Split-Dalmatia Official Gazette, 5/2006, pp. 1-6, 2006.

[19] Zavod za prostorno uređenje Dubrovačko-neretvanske županije, Changes and Additions of Dubrovnik-Neretva County Spatial Plan, pp. 32-34, 2010.

[20] Savjet prostornog uređenja države. Kriteriji za planiranje turističkih predjela obalnog područja mora, Ministarstvo zaštite okoliša, prostornog uređenja i graditeljstva: Zagreb, 2009. 